\title{
Impact of environmental and climate conditions on the investment potential of real estate in the belt of the Gulf of Gdansk Coast
}

\author{
Elżbieta Jasińska ${ }^{1, *}$ \\ ${ }^{1}$ AGH University of Science and Technology in Kraków, Faculty of Mining Surveying and Environmental Engineering, Department of \\ Geomatics, al. Mickiewicza 30, 30-059 Kraków, Poland
}

\begin{abstract}
The subject of this publication is to determine what environmental and climatic factors can significantly affect the value of real estate. As a research object, there was chosen area surrounding the Gulf of Gdansk, which, like the entire coast, is attractive for investment and constitutes an interesting object as a space with a special focus on tourism, including short-term rental. Progressing climate change is particularly affecting this sector. It is safe to assume that unfavorable environmental conditions can significantly change the attractiveness of this area. Therefore, the research hypothesis about the correlation between climate aspects distinguishing the coastal belt and the distribution of real estate prices in the selected area has been verified. The area of the Gulf of Gdansk Coast and the technical and protective belt were analyzed. The weather situation on the coast is different from that prevailing in the rest of the country. There are strong and gusty winds, local floods, but at the same time a natural landscape, proximity to the sea and clean, iodized air. Other possible climatic factors have also been tracked, i.e. temperature, sea level and possible changes that may occur over the next years. The analyzes were based on the data of the KLIMAT project entitled "The impact of climate change on the environment, economy and society", and the Government Project KLIMADA and SPA analyzes. An in-depth analysis of the problem of combining planning documents for the maritime sector influencing the Study of Spatial Development of Polish Marine Areas with Local Spatial Management Plans, introduced Flood Risk Maps and Flood Risk Maps was also conducted.
\end{abstract}

\section{Introduction}

The real estate, in the era of economic stabilization, is an investment which, in most cases, may take on value over time. It is estimated that such a deposit is more profitable than bond investments and safer than shares. In the period of climate anomalies, however, this value may be disturbed. Inappropriate economy as well as weather factors, the consequences of which cannot be predicted, may make the property currently very attractive, cease to exist, or its function to change. The climate on the coast is monitored and forecasted for many years, mainly by the Institute of Meteorology and Water Management National Research Institute. These studies are based on IPCC (Intergovernmental Panel for Climate Changes), data from the World Meteorological Organization (WMO) and their own. Among the most important factors are worth mentioning here: average monthly air temperature, rainfall (both their intensity and the number of rainy days), winds, storm surges, sea level, wave, sea ice [1]. Among coastal investments, it is possible to distinguish several segments focused on profit resulting from tourism, which are successively to the most luxurious:

- hotels and apartments with higher standards,
- accommodation facilities provided for short-term rental: ○ being independent residential premises - mainly located in the city,

o about parts of single-family homes - located on the outskirts, including at the beaches,

- land properties for camping sites and campsites.

\section{Analysis area}

The research area covers the area of Gdańska Bay and towns located on the Gulf of Gdańsk together with the Hel Peninsula. The Tri-City (Gdańsk, Gdynia, Sopot) is distinguished as the area with the highest concentration of population, there are municipalities and cities with the highest demographic and investment dynamics, in which there are more land invested for housing purposes, and for commercial services (area functional agglomeration - ring of municipalities). The advantage of the analyzed areas should also be added to the favorable microclimate and cultural attractions of Gdańsk. At the same time, it is an area that profits from tourism, depending on climatic factors, especially in May-September. In the years 20142016, in the Pomeranian Voivodeship, tourism generated the largest income in the poviat of Gdańsk, where in 2014 it amounted to over PLN 15.3 million of income [2].

$\bar{*}$ Corresponding author: jasinska@agh.edu.pl 


\section{Climatic conditions}

Listing the subsequent climate conditions of the bay, it is worth paying attention to those that are particularly related to tourism: temperature, precipitation and wind power - these factors directly affect the comfort of vacationers. An additional factor important for the real estate market is the sea level and flood zones, which pose a threat to existing tourist facilities.

\subsection{Temperature}

In the coastal region there are specific thermal conditions due to the influence of the Baltic Sea. In winter, the coastal belt is the warmest region in Poland, with an average temperature of $0.0^{\circ} \mathrm{C}$, both as in autumn $\left(9.0^{\circ}\right.$ $\mathrm{C})$. In the spring $\left(6.8^{\circ} \mathrm{C}\right)$ and summer $\left(16.5^{\circ} \mathrm{C}\right)$, these areas are in turn the coolest region, where the average temperature in Poland is $17.0^{\circ} \mathrm{C}$ (data for 2017 [3]).

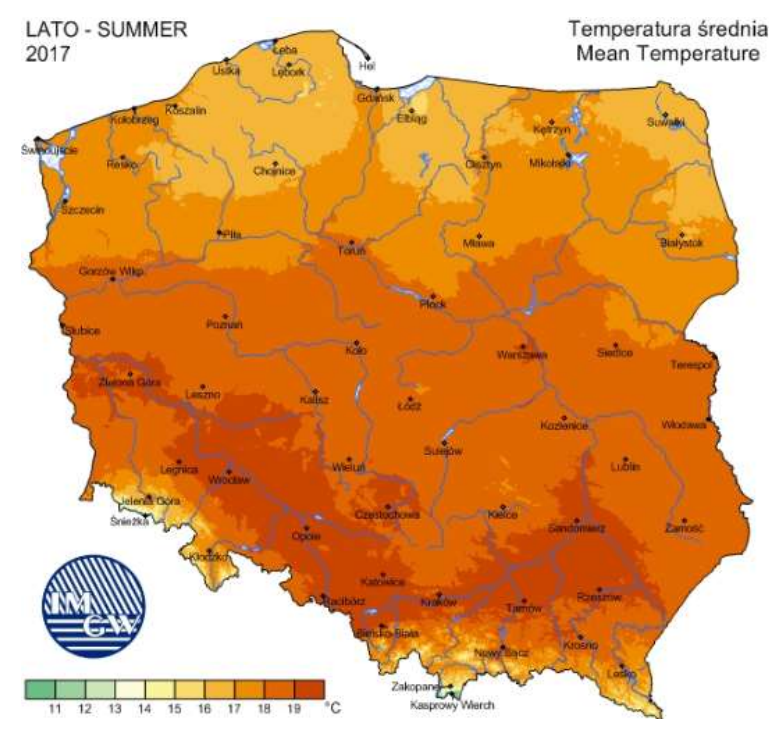

Fig. 1 Average temperatures in Poland in the summer of 2017

Comparing the spring-summer period between Kraków and Gdańsk, or Sopot, a 4-5 degree difference in average temperatures is noticeable. At the same time average air temperatures on the Hel Peninsula are lower by 1-2 degrees than the air temperature in the Tri-City. In order to determine the pace and direction of changes in the average air temperature on the coast and in Poland, in the years 1951-2010, the values of the trend coefficient for the series of mean area temperature in the season scale were determined. In the case of the winter and spring season, the size of changes is greater - in winter it is $0.3^{\circ} \mathrm{C}$ $/ 10$ years, and in the spring $0.4^{\circ} \mathrm{C} / 10$ years. In the summer and autumn, the observed increase in the average air temperature is lower and amounts to $0.2^{\circ} \mathrm{C}$ and $0.1^{\circ} \mathrm{C}$, respectively, per decade [3]. Therefore, one should not expect significant temperature increases. The characteristic of climatic conditions on the coast is complemented by the analysis of the frequency of occurrence of thermal characteristic days, i.e. the days when the air temperature values were recorded from strictly defined intervals. There is a clear systematic increase in the number of hot days per year and systematic lengthening of periods with high air temperature. This makes the area attractive in terms of vacation in the summer, increases attractiveness compared to the rest of the world, but it takes time for such a conviction to be accepted by the tourist market. However, this poses a risk of increasing the water temperature and a decrease in salinity favors the development of thermophilic phytoplankton species, intensifying the mass blooms of cyanobacteria and algae.

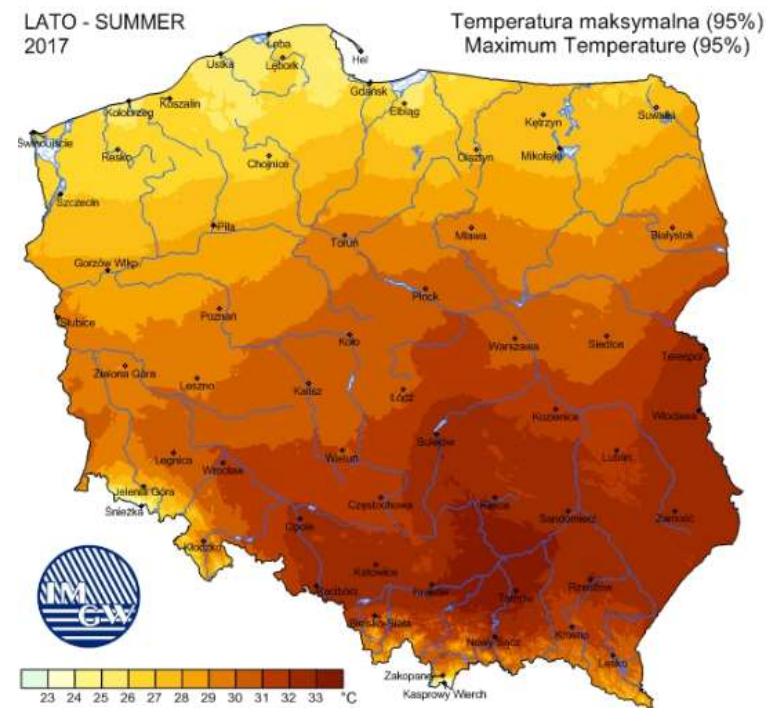

Fig. 2 Maximum temperatures in Poland in the summer of 2017

\subsection{Rain and wind force}

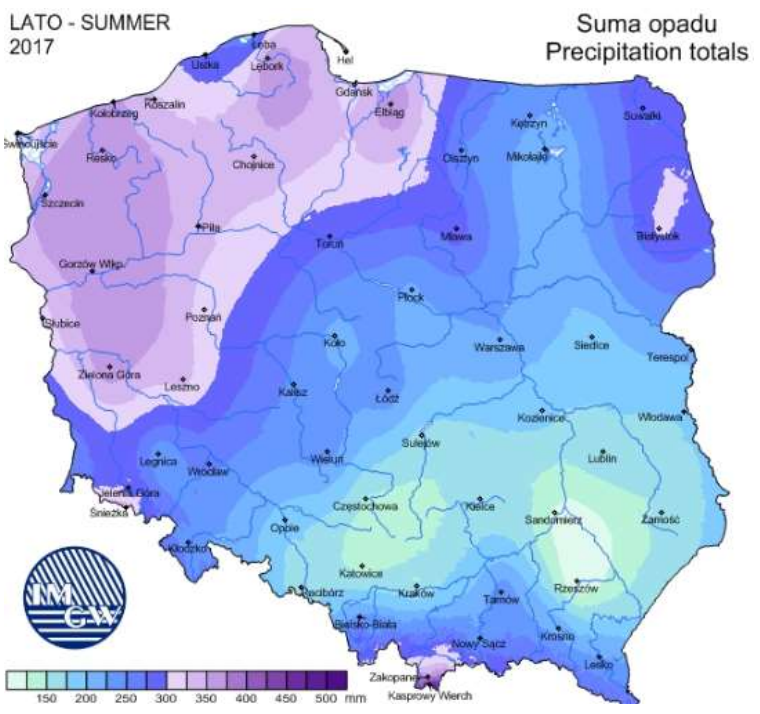

Fig. 3 The sum of rainfall in 2017 in the summer

In recent years, an increase in the occurrence of extreme phenomena - including precipitation - has been observed around the world. Intense rain and maximum wind speeds are the biggest threat to humans for the coast, because they 
contribute to flooding and to the so-called flash flood short-term rains causing floods and local floods. Nowadays, any uncontrolled rise of rivers or the sea causes huge losses, as they almost always expose buildings located in areas threatened by flooding. Precipitation is very diverse in Poland. The smallest precipitation is in the middle region of $500 \mathrm{~mm}$, by 900 $\mathrm{mm}$ on the coast to over $1600 \mathrm{~mm}$ in the Tatras, as indicated in Figure 3 [3]. However, according to the author, the key here are the holiday months, in which the income from tourism are the largest, these are shown in Figure 3.

\subsection{Sea level and flood zones around}

Sea level plays an important role in long-term analysis. From insight into small differences in altitude in the studied area, even slight fluctuations will significantly affect the territorial range of beaches, campsites or other sites for tourist purposes. On the other hand, there is the problem of the Vistula basin and the need for flood protection resulting from this threat. Thus, the areas that are the most exposed are the- from the sea, the Hel Peninsula, on the part of the Vistula River Basin. In the KLIMAT project [3] long-term changes in sea levels, including on Hel and Gdansk, in $10 \mathrm{~cm}$ intervals from 1955-2008 and for comparison for the reference period 1971-1990. On Helium, it was observed that in the range of 500-510 cm levels, the levels from 1955-2008 were more frequent ( $63 \%$ compared to $50 \%$ from the reference period), while in the range of higher values the levels from the reference period were more frequent (Figure 4). In Gdańsk, the situation is reversed, the higher values in the range 510-520 covered the period 1955-2008, falling to the reference period of 500-510 and above 520. In conclusion, it can be noted that the trend is increasing for Gdańsk, but for Hel by long-term study of sea level it stays on the border $500-510 \mathrm{~cm}$. It is expected that the average annual sea level will increase in the period 20812100 from about $20 \mathrm{~cm}$ to about 28 . There is predicted an increase in the threat of the Hel Peninsula and intensification of erosive changes in the central part of the coast (Władysławowo - Jarosławiec). Ask yourself a practical question about the extent of impact of changes in sea level on the real estate market. According to the KLIMAT project analysis [3] the following effects of sea level rise for spatial management and construction can be mentioned:

- loss of at least $120 \mathrm{~km}^{2}$ due to marine erosion, narrowing of beaches and shifting of the shoreline to the area of the current land (reduction of the tourist attractiveness of the area),

- erosion of back-office facilities and destroying wristbands and breakwaters,

- rising groundwater level and salinity,

- elevation of groundwater in low-lying areas to $+1.25 \mathrm{~m}$ above sea level which will limit the future use of many areas for residential and industrial purposes,

- about 300,000 people in the area of direct risk, ie directly exposed to the effects of climate change (loss of housing) - forecast for the entire Baltic Sea,
- the need to tighten up the standards related to the use of waterproof insulations, to stop the use of lightweight type moisture insulation,

- necessity of additional protection of historic buildings.

The most difficult situation is Jastarnia, which is mostly a flood risk area once in a hundred years, but the prices of real estate in this town are high, although most built-up areas are located in the flood risk zone (Figure 4).

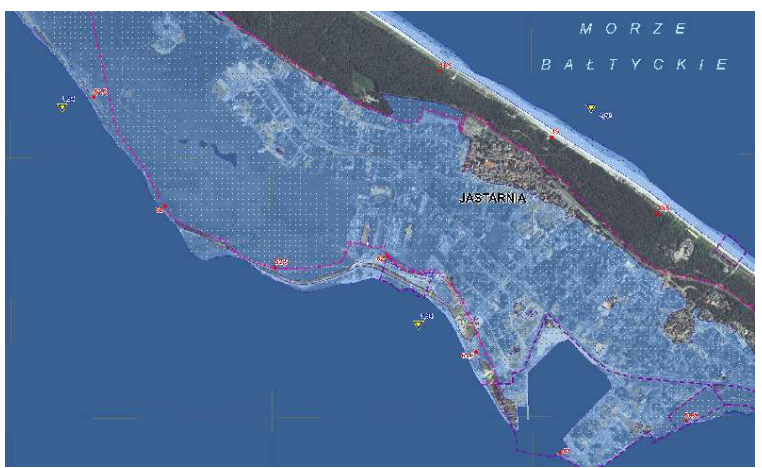

Fig. 4 Flood hazard area in Jastarnia

While the Baltic Sea clearly threatens the Hel Peninsula, the city of Gdańsk is still a threat to the city, and the Vistula river basin is still very close (Martwa Wisła and Motława). It is worth to appreciate the scope of planning activities carried out on the basis of flood analysis $[4,5,6]$. The threat coming from this title will be the result of a flood within the country, which in the form of a climax will reach the city. The extent of the occurrence of such a threat concerns mainly the eastern part of the analyzed areas, as shown in Figure 5.

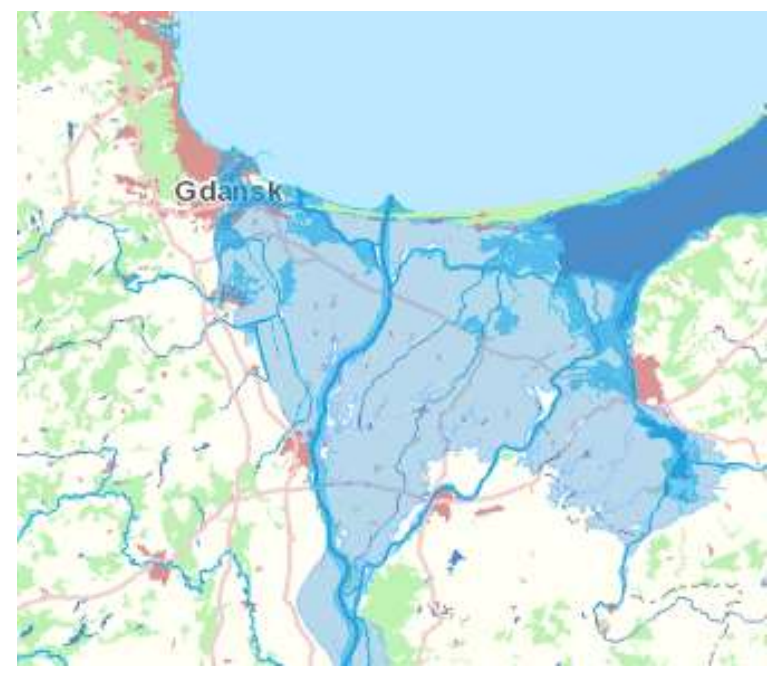

Fig. 5 Flood risk map for the vicinity of the City of Gdańsk

\section{Touristic}

Due to its popularity, Gdańsk Bay gives way to the leader which is Kołobrzeg, but it can boast of an unusual combination of several different cities located at a short distance. The Tri-City is perfectly connected and uses it combining three different cities: Gdańsk (a city with an airport and many monuments, eg. Westerplatte), Sopot, 
which is noticed by tourism solstice, which may affect regional policy in the coming years (e.g. limitation of short-term rental) and Gdynia - the most-visited city in the area, however, selected for one-day stays (5 million tourists in 2016, of which only 400,000 for more than 3 days). Also, it is not limited to tourists from Poland, but they are the main customers. On the basis of analyzes of static data from the previous year, we can notice over 800 thousand tourists visited Gdańsk alone, of which about 250 thousand did not take advantage of accommodation during their stay, Sopot is the accommodation base, whose main attraction is a million tourists a year (data based on tickets sold). In the earlier chapters, mainly tourism was mentioned, but it is worth explaining that (mainly Gdańsk) this tourism is not limited to the summer season [2]. The network of routes in the coastal area includes internal and international routes, urban tourism, sightseeing and conference tourism dominating in the TriCity. In addition to beautiful beaches and forest facilities, you will also find conditions for sailing, windsurfing and kitesurfing, diving in search of underwater treasures and wrecks. The accommodation offer is very diverse starting from 5 stars hotels, apartments through holiday centers to campsites. The challenge for local governments is to operate the coastal areas, which will benefit the communities, while enjoying the natural resources without neglecting the biological balance, which is unique and is one of the reasons for traveling to a given place. Unsuitable coastal areas can cause faster degradation and erosion of beaches, cliffs and dunes. elaboration of the Spatial Development Study plans to use natural and cultural resources to improve the development of tourism, these are, first of all, marina moors, walkways, footbridges, bridges. Currently, the most important holiday centers are Gdańsk, Gdynia, Sopot, Jastarnia, Jurata, Hel, Krynica Morska, Puck.

In addition, there are objections from the local community - the loudest of conflicts concerns the Lower Sopot, which is dominated by the short-term rental market and therefore real estate there are treated as investments. However, this raises the objection of the other residents, who press Barcelona to prohibit short-term rent. Looking at the Doxey model, you can expect growing conflicts in this topic [7].

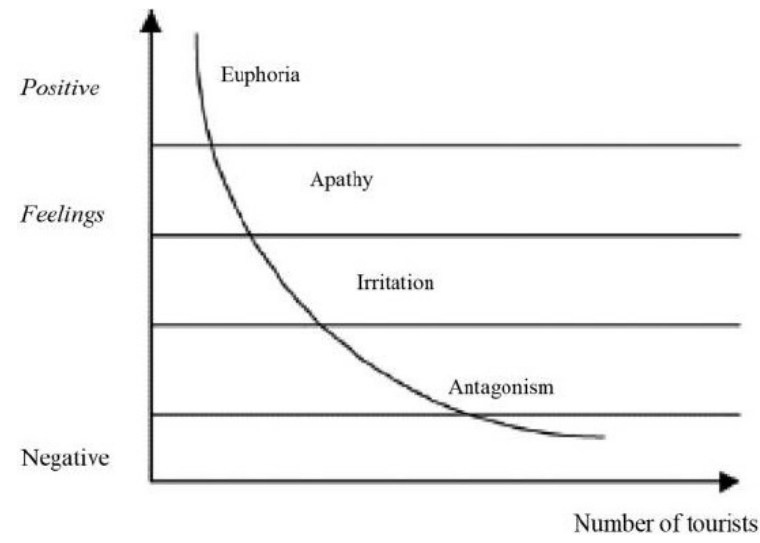

Fig. 6 The Doxey model of the attitude of the local community to tourists, depending on their number

\section{Real estate market}

\subsection{Real estate housing}

Analyzing the average prices of premises, the market should be divided immediately because:

- The surrounding area (proximity to tourist attractions).

- Floor area of the premises (in the rental perspective, it can be converted into the number of people available for accommodation, the number of rooms to be rented).

- Primary market (if possible) and secondary market.

The prices of real estate with an area exceeding $80 \mathrm{~m}$ are above the transaction and offer average on the primary market - PLN $7500 / \mathrm{m}^{2}$, while the rest of the flats rank at the same level as the average - except for small flats, i.e. below $40 \mathrm{~m}^{2}$, there are $250 \mathrm{PLN} / \mathrm{m}^{2}$ cheaper. The situation on the secondary market is reversed, prices per $\mathrm{m} 2$ of small apartments are higher than those with large premises. It is profitable to buy large premises over $80 \mathrm{~m}^{2}$ on the secondary market - a difference above 2 thousand $/ \mathrm{m}^{2}$, or small apartments on the primary market. Selected (the most attractive locations) along with the average prices of premises are presented below [8], and show in Figure 7:

- Gdańsk (average) - 7000 PLN $/ \mathrm{m}^{2}$ ( $+12 \%$ per year)

○ Przymorze wielkie - $11000 \mathrm{PLN} / \mathrm{m}^{2}$ ( $+22 \%$ per year),

○ Brzeźno - $12000 \mathrm{PLN} / \mathrm{m}^{2}$ (+6\% per year),

○ Żabianka - Jelitkowo $8500 \mathrm{PLN} / \mathrm{m}^{2}$ (+ 7\% per year).

○ Nowy Port $5000 \mathrm{PLN} / \mathrm{m}^{2}$ ( $+2 \%$ per year),

o Stogi $6500 \mathrm{PLN} / \mathrm{m}^{2}(+12 \%$ per year $)$,

- Hel $10600 \mathrm{PLN} / \mathrm{m}^{2}$ (-17\% per year)

- Sopot (average) - $13719 \mathrm{PLN} / \mathrm{m}^{2}$ (+5\% per year)

- Sopot Górny -7 266 PLN/m² (-7\% per year)

- Sopot Dolny - $14253 \mathrm{PLN} / \mathrm{m}^{2}$ (+2\% per year)

- Jurata $23042 \mathrm{PLN} / \mathrm{m}^{2}$ (+59\% per year)

- Jastarnia $21950 \mathrm{PLN} / \mathrm{m}^{2}$ (+23\% per year)

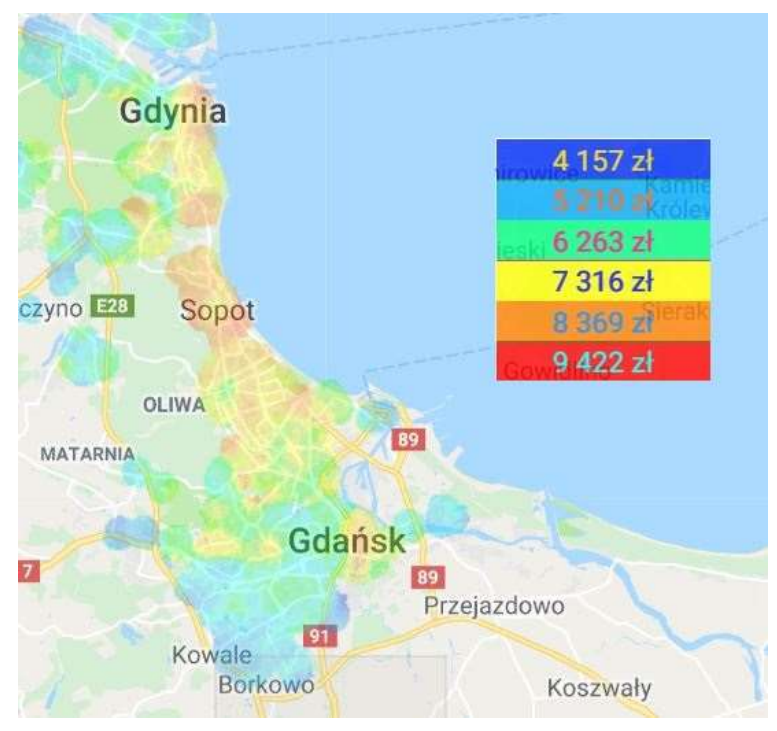

Fig. 7 Map of average prices of housing properties for the TriCity

Prices in Sopot Górny are close to prices in Gdansk, but the division into the part intended for tourists and 
residents is very visible here. Prices in Sopot Dolny (by the beach and pier) are much higher, because due to the lack of new areas it is difficult to find new investments here, and transactions are based on the secondary market. The real financial benefit will be generated here even by the square designated for parking, because despite the introduction of parking zones, the area is heavily laden with car traffic, which further exacerbates narrow streets, yet limiting parking spaces [8].

The immensity of real estate prices in Jurata is very characteristic of the real estate for renting tourists - it is caused by the construction of the exclusive Marina Jastarnia apartment building designated for short-term rental. Gdańsk also makes such investments, including Aparthotel Number One, Aparthotel Neptun, and Aparthotel Grodzka 10. Of course, these are investments with a high level of customer service and a higher standard, according to Home Broker analysts - they guarantee profits of $6 \%$ per year [9]. An incentive to buy the apartment may be a guaranteed rate of return. It is usually carried out in the form of a lease agreement for premises, concluded for a definite period between the owner and the management company, and defining all basic conditions, including the determination of the annual rent payable in monthly installments. Parallel to them, there are standard solutions like apartments in blocks, or separated fragments of single-family houses, which are rented to tourists.

\subsection{Land real estate}

Land real estate will no longer be as numerous on the market as housing properties (or their derivatives), they will also be limited mainly to coastal areas or located on the periphery. Returning to the previous chapters, it is worth mentioning their main advantage here - without additional investment expenditures they can bring financial benefits constantly, serving as a parking lot or a camping site $[10,11]$. Their main disadvantage will be exposure to rain or a flood hazard - which can completely exclude them from profit. The main factors that can disturb this balance are increased storms and rainfall, which increase the risk of flooding. A characteristic feature of the flood hazard is the occurrence of storm floods that pose a threat to port and coastal cities. Analyzing the threat in the water region of the coast, on the one hand, one should consider the threats originating from the mass of the Baltic Sea, ie storm storms, and on the other hand, the influence of a flood wave in estuaries should be considered [12]. River polder floods also occur in this region, but they relate to depression and depression areas from $-1.8 \mathrm{~m}$ to $2.5 \mathrm{~m}$. However, these prices can be balanced by an increase in average temperature, which will positively affect the economic and tourist development of Pomerania, and also Zachodniopomorskie Province. In order to verify the situation on the real estate market, it was decided to develop an appraisal study of the valuation of undeveloped land in Jastarnia on the Hel Peninsula.
The subject of valuation is an undeveloped landed property No. 10/20 located in Jastarnia at ul. Sztormowa 10, Pażeca housing estate, Puck poviat, Pomeranian Voivodeship, area 0.0725 ha [10]. It is a standard plot area in this area, and the whole city has about $8 \mathrm{~km}^{2}$ area. It has a fairly well-developed service infrastructure and average transport connections with all parts of the city $[13,11]$. It is also a region abundant in green areas. Land properties offered for sale in this area are land with a small area. The following features can be attributed to the plot being valued [14]:

- Attractiveness of locations - medium (0)

- Neighborhood and surroundings - favorable (2)

- Technical infrastructure - good (2)

- Shape and size of the plot - good (2)

- Flood danger - medium (0) - this attribute is particularly important in the long term

- Destiny in LDP - very good (2) - (MNU) as areas with predominant single-family residential - service function.

For the market analysis, real estate with an area of $402 \mathrm{~m}^{2}$ to $840 \mathrm{~m}^{2}$ located within the new housing estate was selected. Information was collected on 13 land properties, which in the last 15 months were subject to market transactions. The real estate being the subject of the right of ownership was selected for the valuation. Unit transaction prices range from PLN $1080 / \mathrm{m}^{2}$ to PLN 3 $400 / \mathrm{m}^{2}$. The similarity of selected properties to the valued property was formulated using the 6 attributes listed in the previous paragraph.

On the basis of the analysis of similar real estate, it can be concluded that in the analyzed set of information about a market transaction on real estate, time-adjusted prices depend first of all on the danger of flooding, and further on the attractiveness of location and equipping with technical infrastructure (Fig. 8)

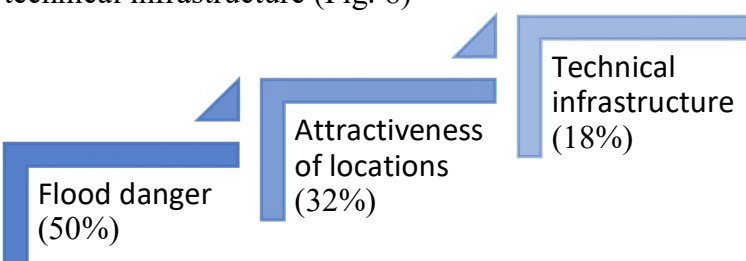

Fig. 8 The most important valuable affecting the prices of real estate in the city of Jastarnia

Out of 13 previously analyzed properties, 5 of them, which have the most similar attributes to property valued, were used for the valuation using the pair comparison method. 5 properties were selected as similar real estate, two of which are not threatened by flooding. The quota share of this feature (flood risk) was PLN 1234, the attractiveness of the location was PLN 790, and the infrastructure was PLN 444. On the basis of the analysis of the market of similar land properties to the valued real estate and based on the calculations according to the pairwise comparison method, it follows that the market value of the valued real estate is PLN 1124142 (in words: one million one hundred and twenty four thousand one hundred and forty two zlotys). It can be noticed that areas that are threatened by floods are lower by over $50 \%$. In 
earlier considerations taking account of changes in the Local Development Plan for the value of the property [5], also described in the project Computer Information System of the Country against extraordinary threats, it was proposed that these changes will be $60 \%$, which together with the increase of the water depth above $2.0 \mathrm{~m}$ (case of Jastarnia), property loss values will be reduced depending on the voivodships. For the Pomorskie Voivodeship, the average value of land for residential development is PLN 399.89, industrial areas PLN 595.82. The list of problem areas exposed has been described in the FRMP Project, among others Ustka, Puck, Gdynia, Władysławowo, Jastarnia, Hel, Gdańsk, Krynica Morska - port cities that are threatened by the impact of sea waters, especially Jastarnia, where almost all of it is threatened with water up to $2.0 \mathrm{~m}$. Another problem is the erosion of the shores that is progressing on the Hel Peninsula caused by stronger storms causing waves and picking up sand, which leads to increased vulnerability of the area to storm waves. Threats to the coastal areas are also strong winds, which increase the damming up of the waters by the sea and the Bay of Puck.

\section{Conclusions}

The real estate, in the era of economic stabilization, is an investment that can take on value over time. It is estimated that such a deposit is more profitable than bond investments and safer than shares. During the climate anomalies, however, this value may be disturbed. Inappropriate economy as well as weather factors, the effects of which we cannot prevent, may cause that the real estate currently attractive, cease to exist, or its function to change.

The climate on the coast has been described on the basis of the projects of the Institute of Meteorology and Water Management - National Research Institute. These studies are based on IPCC (Intergovernmental Panel for Climate Changes), data from the World Meteorological Organization (WMO) and their own. The condition of the most important factors that may affect the coastal area, ie temperature, precipitation, winds, storm surges, sea level, wave, sea ice, has been described. The temperature for the coast has an upward trend and is on average $0.2^{\circ} \mathrm{C} / 10$ years. The number of hot days increases as well as their length, and the number of days with cold waves decreases along with the duration of these waves. It is forecasted that the average annual temperature up to 2100 will increase by $3 \mathrm{oC}$, depending on the scenario, namely whether there will be increased activities to slow down this process. It is expected to increase the number of mild winters in the coming years, which also results in the structure of ice severity at sea, which has a protective function against erosion, i.e. in the South Baltic will mean a greater number of days with the initial ice forms. A good snow small units dangerous for sailing.

Also atmospheric precipitation has an impact on the coastal areas. Currently, the biggest threat to humans are flash floods - short-term rains causing floods and local floods. The highest rainfall can be observed in the summer, where it reaches its maximum in August.
A decreasing number of days with precipitation of the socalled continuous small $<1 \mathrm{~mm}$, and longer periods (droughts) to 5 days, with simultaneous increase in the number of days with rainfall $>10 \mathrm{~mm} /$ day. Such high instability of intense rainfalls can contribute to causing droughts alternating with floods and violent floods. Strong winds identify with the coastal climate, where there were exceeded the maximum annual wind speed in gusts above $40 \mathrm{~m} / \mathrm{s}$. Whirlwinds and squalls are an increasingly frequent sight, and an increasingly devastating element that can not be controlled. The sea level is variable and each town located on the shore has different values. It is caused by tides, estuaries of rivers in the area or strong winds that push water on land. The frequency of occurrence of the average annual sea level in the years 1955 - 1981 was $505 \mathrm{~cm}$, while from 1982 this level increased by $10 \mathrm{~cm}$. It is forecasted that by 2100 , the average annual sea level will increase by $20-35 \mathrm{~cm}$, it is much smaller than the forecasted future level of the world's ocean, which will range from $26-82 \mathrm{~cm}$. Note that the sea level rise by $1 \mathrm{~cm}$ does not mean the absorption of $1 \mathrm{~cm}$ wide land [12]. Polish coastal regions are depressing regions, where the $1 \mathrm{~cm}$ sea level can mean a belt with a width of, for example, $10 \mathrm{~m}$, and certainly increase the risk of flooding of areas located further away from the sea. An increase is expected in 88 threats to the coasts of the Hel Peninsula, the Vistula Spit with Krynica Morska, Puck and Gdynia, as well as depression areas of Żuławy. Rising sea levels in combination with low coastal areas can increase the negative effects of storms that are increasing and occur mostly from December to February. The decreasing ice cover facilitates the operation of storms that threaten the coastal zone.

In conclusion - in the near future it will be the most important factor that will affect the value of the property located on the coast. Technical conditions that are being developed will certainly take into account durability and insulation of foundations, protection with a shaft, wall or wall, interior and equipment protection, etc. - each of these options exposes us to additional costs compared to buildings built on secure land.

Land prices by the sea start on average 2000 PLN/qsm around $3000 \mathrm{PLN} / \mathrm{sqm}$ in the close vicinity of water. The highest prices were recorded in Sopot. The prices of flats can reach an above-average level of the upper limit, but by defining it, one can accept the 15th Hel Peninsula in Jurata, followed by Sopot (near Jelitkowo). Most preferably, they are coastal properties, because they migrate the areas near the beltway and rent their apartments.

\section{Acknowledgement}

Publication supported by the Polish Ministry of Science and Higher Education as a part of the program of activities disseminating science from the project „Organization of the First International Science Conference - Ecological and Environmental Engineering”, 26-29 June 2018, Kraków.

This work was carried out within the statutory studies of the AGH University of Science and Technology. Faculty 
of Mining Surveying and Environmental Engineering. Department of Geomatics No. 11.11.150.006.

\section{References}

1. http://www.isok.gov.pl/pl/

2. http://stat.gov.pl/

3. http://old.imgw.pl/klimat/

4. M. Mika, M. Siejka, P. Leń, Ż. Król . The concept of using the water cadastre databases components for the construction of multi-dimensional cadastre in Poland. Survey Review, (2016)

5. M. Siejka, M. Mika, T. Salata, P. Leń. Algorithm of land use spatial data processing for the local flood risk mapping, Survey Review (2017)

6. P. Hanus, A. Pęska-Siwik, R. Szewczyk. Computers and Electronics in Agriculture, 144, p. 9-15. (2018)

7. G. Doxey. When enough's enough: the native are restlessin Old Niagara, „Heritage”, Canada, 2 (1976)

8. ceny.szybko.pl

9. http://trojmiasto.wyborcza.pl/trojmiasto/7,153581,2 1410861,mieszkanie-pod-wynajem-w-gdansku-sieoplaca-w-gdyni-nieco.html

10. P. Hanus, E. Jasinska, Preweda, E. Analysis of the accuracy of determining the coordinates property borders. In Environmental Engineering. Proceedings of the International Conference on Environmental Engineering. ICEE (Vol. 9, p. 1) (2014).

11. E. Jasińska. Real Estate Due Diligence On the Example of the Polish Market. 14th SGEM GeoConference on Informatics. Geoinformatics and Remote Sensing 2. SGEM2014 Conference Proceedings. June 19-25. 2014. Vol. 2. (2014)

12. E. Jasińska, E. Preweda. Effect the accuracy of benchmarks to establish of the determination of geodetic network. In: the 9th International Conference Environmental Engineering : May 2223, 2014, Vilnius, Lithuania: selected papers. (2014)

13. K. Butryn, E. Preweda, Analysis of the impact of quantitative and qualitative price-setting attributes on a market of real estate intended for the purpose of the transformer stations on the example of Krakow. The 10th International Conference Environmental Engineering : selected papers : April 27-28. 2017. Vilnius. Lithuania. (2017)

14. E. Jasińska. Land use efficiency on example of the transformation of rural properties. The 10th International Conference Environmental Engineering: selected papers: April 27-28. 2017. Vilnius. Lithuania. (2017). 